\title{
Dakwah Tuan Guru Baba Abdulkarim bin Hasbullah Naknawa
}

\author{
Miss Yamilah Salaeh ${ }^{1 *}$, \& Asep Shodiqin ${ }^{1}$ \\ Jurusan Komunikasi dan Penyiaran Islam, Fakultas Dakwah dan Komunikasi, \\ UIN Sunan Gunung Djati, Bandung \\ *Email:yamilahsalaeb570@gmail.com
}

\begin{abstract}
This study aims to obtain a factual description in the form of an explanation of the mission of Mr. Guru Baba Abdulkarim. This research was conducted at Pondok Dala Islamic Boarding School in Pattani. Data collected through involed observations, in-depth interview and literature. Data analysisi is carried out inductively through interpretation of information related to social context. In this study explained that the master of the Baba theacher has a variety of methods and matrials in delivering his message. Among the tabligh methods used by maters Baba is the lecture method, the question and answer method, discussion method, halaqah method and exemplary method. The result of this study that the teacher has a different tabligh method and have different material depending on how the condition of the community, so that the theme delivered can also be in accordance with the circunstances at that time. Jema'ah tabligh a good response to tabligh Mr. Baba, so that every time there is a recitation of the Mr. Baba, the pilgrims come in droves from all over the region.
\end{abstract}

Keywords: Dakwah; Mubaligh; Pattani

\begin{abstract}
ABSTRAK
Tulisan ini bertujuan untuk memperoleh gambaran factual berupa penjelasan tentang dakwah Tuan Guru Baba Abdul Karim Bin Hasbullah Naknawa, penelitian ini dilakukan di Pesantren Pondok Dala di Pattani, penelitian ini menjelaskan tentang bagaimana proses dan cara dakwah Tuan Guru Baba. Tulisan ini dilakukan dengan cara metode kualitatif dan data diambil secara purposif. Data dikumpulkan melalui observasi terlibat, wawancara mendalam dan kepustakaan. Analisis data dilakukan secara induktif melalui interpretasi informasi dihubungkan dengan konteks social. Dalam tulisan ini dijelaskan bahwa Tuan Guru Baba memiliki berbagai macam metode dan materi dalam menyampaikan dakwahnya, diantara metode tabligh yang digunakan oleh Tuan Guru Baba adalah metode ceramah, metode tanya jawab, metode diskusi, metode halaqah dan metode keteladanan. Hasil penelitian ini bahwa Tuan Guru Baba memiliki metode tabligh yang berbeda - beda dan memiliki materi tabligh yang berbeda pula tergantung bagaimana kondisi masyarakat sehingga tema yang disampaikan bisa sesuai dengan keadaan pada waktu itu. Jema'ah tabligh juga memberikan respon yang
\end{abstract}


M. Y. Salaeh, \& A. Shodiqin

baik terhadap tabligh Tuan Guru Baba, sehingga setiap kali ada pengajian Tuan Guru Baba maka para jema'ah datang berbondong - bondong dari seluruh wilayah.

Kata Kunci : Dakwah; Mubaligh; Pattani

\section{PENDAHULUAN}

Dakwah Islam pada dasarnya ada sejak zaman Nabi Muhammad SAW, namun bentuk dan cara penyampainnya berlainan, yakni disesuaikan dengan situasi dan kondisi masyarakat sekitar. Dakwah dapat dilaksanakan dengan berbagai metode, seperti ceramah, diskusi, Tanya jawab, keteladan, karyawan, lisan-hal dan hikmah. Untuk menyampaikan pesan dakwah seorang juru dakwah (da'i) dapat menggunakam berbagai macam media dakwah, baik itu menggunakan modern (media elektronika) maupun media tradisional (Amin, 2000:120).

Secara teologis dakwah merupakan bagian dari tugas suci (ibadah) umat Islam. Kemudian secara sosiologis kegiatan dakwah apapun bentuk dan konteksnya akan dibutuhkan oleh umat manusia dalam rangka membutuhkan dan mewujudkan keshalehan individual dan keshalehan sosial, yaitu pribadi yang memiliki kasih sayang terhadap sesamanya dan mewujudkan tatanan masyarakat marhamah yang dilandasi oleh kebenaran tauhid, persamaan darajat, semangat persaudaraan, kesadaran akan arti penting kesejahteraan bersama, dan penegakkan keadilan di tengah-tengan kehidupan masyarakat.

Berdasarkan pada beberapa alasan di atas, maka dakwah memiliki makna dan arti yang begitu penting bagi kehidupan umat manusia. Oleh sebab itu, cukup beralasan jika dibutuhkan pemaknaan dan pemahaman baru terhadap dakwah.Apalagi jika didasarkan pada kenyataan masih banyaknya pemahaman masyarakat mengenai dakwah baik dikalangan alim apalagi dikalangan masyarakat awam yang masih menngindentikan dakwah sebatas tabligh atau khitabah.

Sekalipun betul secara umum bahwa persepsi dan pemahaman masyarakat tentang dakwah telah mengalami sedikit perubahan. Misalnya, pada masa lalu dan mungkin juga masih tetap pada sebagian masyarakat sekarang, masih juga mengartikan dakwah secara praktis sama dengan ceramah (tabligh atau khitabah), yaitu proses atau kegiatan menyampaikan ajaran islam secara lisan yang dilakukan oleh penceramah di atas mimbar, dalam pengajian-pengajian di majlis taklim atau ceramah pada peringatan hari-hari besar islam. Sehingga sangat dimungkinkan ketika orang berbudi pekerti yang terpuji dan menolong orang yang membutuhkan batuan, mempereratkan persaudaraan, meningkatkan kesejahteraan dan menegakkan keadilan bukan sebagian dakwah. Karena itu, wajar jika Nurcholish Majdid menegakkan bahwa dakwah sekarang harus ada perubahan, sebab kalau tidak, dakwah akan kehilangan makna dan subtansinya. Tabligh dapat diartikan dari dua sudut pandang, yakni pengertian tabligh yang bersifat pembinaan dan bersifat pengembangan. Tabligh yang bersifat pembinaan adalah usaha untuk mempertahankan, elestarikan, dan menyempurnakan umat 
manusia agar tetap beiman kepda Allah swt, sedangkan tabligh yang bearti pengembangan adalah usaha mengajak manusia yang belum pernah beriman kepada Allah swt agar memeluk agama islam. Salah satu cara tabligh adalah khitobah atau ceramah, yaitu suatu teknik atau metode tabligh yang banyak karakteristik bicara seorang penceramah atau mubaligh pada aktivitas tabligh. (Syukri, 1983 :104).

Jamaah tabligh merupakan pergerakan islam yang mendunia, hal ini menjadi fenomena perjuangan islam di jaman sekarang ini. Pergerakan jamaah tabligh ini sangat cepat dan mudah diterima oleh pengikutnya. Jamaah tabligh menjadi kelompok islam yang berada disetiap negara Islam. Gerakan islam bernama jamaah tabligh ini menimbulkan dua perspektif di kalangan ulama, hal ini merupakan hal biasa. Karena setiap perspektif ulama atau orang pastilah berbedabeda tidak selalu sama.

Sebagaimana jamaah tabligh ulama-ulama Fathoni dan ualama-ulama Nusantara lainnya, ia belajar di pondok-pondok setempat. Jika sebagian ulama Pattani setelah menyelesaikan pelajaran menlanjudkan pendidikannya di timur tengah atau tempat-tempat di luar negeri, tidak demikian dengan Tuan Guru Haji Abdul Karim bin Hasbullah. Ia tidak belajar keluar negeri pendidikannya hanya di pondok-pondok di pattani, namun dijalani dengan penuh kesungguhan, keikhlasan, dan dialaui dalam waktu yang lama.

Dalam Al-Qur'an surat An Nahl ayat 125, disebutkan bahwa dakwah adalah mengajak umat manusia ke jalan Allah dengan cara yang bijaksana, nasehat yang baik serta berdebat dengan cara yang baiak pula.

"Serulah (manusia) kepada jalan Tuhan-mu dengan bikmah dan pelajaran yang baik dan bantablab mereka dengan cara yang baik. Sesunggubny-ana Tubanmu Dialah yang lebih mengetahui tentang siapa yang tersesat dari jalan-Nya dan Dialah yang lebih mengetabui orang-orang yang mendapat petunjuk. (Depag RI, 2009)

Al- Quran menerangkan pada kebanyakan suratnya tentang tujuan dari dakwah baru, rukun-rukunnya, hakikat dasarnya. Dari hakikat itu adalah : iman kepada Allah yang Esa, kehidupan akhirat, wahyu dan risalah. juga menanamkan ketentuan dan dasar dakwah, dan menentukan cara dan dasar dakwah, dan menjelaskan cara bagi Rasul yang melia serta para pendakwah sesudahnya (Syihata,1986: 6-7).

Pengertian dakwah dari segi bahasa ini masih memiliki karakteristik yang umum, karena yang namanya mengajak, memanggil atau menyeru bisa saja terjadi kepada kebaikan atau keburukan. Dalam konteks pengertian bahasa al-Qur'an menujukkan contoh-contoh penggunaan kata dakwah. Penggunaan kata dakwah bisa diguna untuk ajakan kebaikan, dan ada juga yang menggunakan ajakan pada keburukan.Kata dakwah dilihat dari segi kosa katanya berbentuk kata dua (isim) yang di ambil (musytaq) dari fi'il madi. Mengandung nilai dinamis yakni ajakan, seruan, panggilan, permohonan. Makna-makna tersebut mengandung unsur usaha atau upaya yang dinamis. Apalagi kalau merujuk pada Al-Qur'an sebagai bentuk 
masdar (ad-dakwah), hamper semua yang ada kaitan dengan dakwah diekspresikan dengan kata kerja (fi'il madi, dan amr) (Muhyidin, 2002 : 27).

Selanjutnya Ahmad Mansyur Suryanegara menyatakan, bahwa dakwah adalah aktivitas menciptakan perubahan social dan pribadi yang didasarkan pada tingkah laku pelaku pembaharunya. Kemudian dalam terminology akademis, dakwah dalam arti makro ekuivalen dengan social reconstruction (rekonstruksi social) social dalam arti ekonimi, budaya, pendidikan, kemasyarakatan, dan lainnya (Muhyidin, 2002 : 28).

Dari beberapa pengertian di atas dapat disimpulkan, walaupun ada perbedaan dan kesamaan, tapi pada hakikatnya dakwa adalah suatu ajakan, bimbingan, dorongan dengan kesadaran di dalam memahami, mencermati dan menghayati ajaran islam untuk kemudian diamalkan dalam berbagai segi dalam kehidupan. Demikian konsep amar ma'ruf nahi munkar harus benar-benar melekat sehingga nilai-nilai ajaran islam dapat terwujud dalam prilaku berkeluarga, bermasyarakat, bernegara dan beragama.

Al-qur'an merupakan kitab suci terakhir yang diwahyukan Allah kepada Nabi Muhammad saw untuk dijadikan sebagai pedoman hidup (way of life) bagi umat manusia. Sebagai pedoman hidup, al-quran dianggap sebagai sumber nilai dan norma pertama di samping al-Sunnah, karena al-qur'an sebagai budan li al-nas, petunjuk bagi umat manusia pada umumnya dan orang-orang yang bertakwa pada khususnya.

Dakwah yang dilaksanakan harus mempunyai tujuan tertentu. Dakwah bertujuan menciptakan suatu tatatan kehidupan individu dan masyarakat yang aman, damai dan sejatera yang dinaungi oleh kebahagiaan, baik jasmani maupu rohani, dalam pancaran sinar agama Allah dengan mengharap ridha-Nya (Ma'arif, 2010 : 26). Tujuan dalam bahasa inggris dapat dipilih dalam beberapa term : target, objective, purpose, aim, dan goal, adalah hal tertentu yang ingin dicapai. Di dalam proses dakwah, tujuan adalah merupakan salah satu factor yang sangat penting dengan tujuan itulah dapat dirumuskan suatu landasan tindakan dalam pelaksanaan dakwah merupakan kegiatan rangkaian dalam rangka mencapai tujuan tertentu. Sebab tanpa tujuan yang jelas, maka kegiatan dakwah akan sia-sia (Aliyudin, 2009 :98).

Menurut Amrul Ahman, tujuan dakwah menjadi dua garis besar yaitu: tujuan jangka pendek (mikro) adalah meningkatkan insan-insan berkualitas, membangun manusia-manusiashaleh, merubah stratifikasi yang rendah menjadi lebih baik dan terhormat. Sendang tujuan jangka panjang (makro) adalah membangun masyarakat yang berkualitas dengan perkataan "baldatun thoiyibatun warabun ghafur" atau disebut masyarakat madani yaitu suasna kehidupan masyarakat yang diliputi oleh manusia yah iman taqwa.

Didalam pesan dakwah merupakan salah satu unsur penting ketika seseorang akan mau berdakwah, maka penting mengetahui karakter atau ciri cirri pesan yang akan disampaikan ketika seseorang akan menggunakan suatu media, baik mimba, media cetak, mau pun elektronik, yang terbesiit dalam pikiran 
penyiar, bukan hanya bagaimana cara menggunakan media - media itu, tetapi juga pesan apa yang akan disampaikan melalui media itu.

Tabligh adalah penyampaian pesan dari pembirian ajaran islam kepada umat manusia, dengan penyampian itu maka pemberi menjadi terbatas dari kewajubannya (menyampaikan ) dengan pihak penerima berita (Subandi, 1994:32). Tabligh salah satu kegiatan yang artinya proses menyeru manusia untuk hidup dijalan Allah agar tercapai kebahagiaan hidup di dunia dan di akhirat. Proses menyeru kejalan Allah yang disebut tabligh dengan lingkungan. Dilakukan dalam rangka pencerdasan dan pencerhan masyarakat melalui kegiatan pokok yaitu : social, internalisasi, dan eksternalisasi ai ajaran islam, dengan menggunakan sarana mimbar massa (cetak dan audio visual) (Muhyidin, 2002:4).

Istilah tabligh dalam Islam secara bahasa adalah paggilan, seruan atau ajakan, sedangkan kata tabligh bearti menyampaikan materi. Kedua arti ini memiliki arti hampir sama. Jika tabligh bearti mengajak seseorang atau kelompok orang unutuk memeluk agama islam, maka tabligh bearti menyampaikan ajaran islam keapada seorang atau kelompok orang dengan tujuan agar orang atau kelompok itu bersedia mem agama islam demi kebaikaan mereka baik di dunia dan akhrat kelak.

Dalam pelaksanaan tabligh memiliki unsur-unsur yang sama dengan unsurunsur dakwah. Adapun unsur-unsur tabligh adalah muballigh, materi tabligh, metode tabligh, media tabligh, dan mubalagh (Kusnawan, 2004:125). Adapun tujuan tabligh Pada dasarnya tujuan sama dengan tujuan dari tabligh tujuan tabligh merupakan diri kepada Allah SWT. Dengan rincian tujuan untuk menyerukan kepada orang kafir agar masuk Islam, menyerukan kepada orang Islam agar melaksanakan hukum Islam secara total.

Jika muslim bisa mennjalankan syariaat ajaran islam maka tujuan tersbut akan didapatkan, yaitu dengan menjalankan yang diperintahkan dan menjauhi segala larangan-Nya, oleh karena itu, setiap mubaligh atau da'i selalu mengarahkan agar umat mengetahui, megimami, menerima serta diharpakn supaya mengamalkan dalam kehidupan sehari-hari. Tujuan muballigh tak lain adalah untuk mendapat nilai spiritual, yaitu untuk mengingatkan hubungan dengan Allah SWT dengan melakukan kegiatan tabligh-tabligh baik secara indibvidu maupun kelompok

Seorang mubaligh harus mengetahui siapa dirinya, apa tujuan dakwahnya, sifat-sifat apa saja yang harus dimilikinya, siapa sasaran dakwahnya, dan sarana serta mtode apa yang digunakannya (Ali al-Qathani, 1994: 94).Muballigh adalah orang yang menyampaikan ajaran islam kepada umat manusia, baik secara langsung maupun seacara tidak langsung. Kata mublalligh berasal dari bahasa Arab bentuk mudza (laki-laki), yang artinya orang yang mengajak, kalau kata muannas (perempuan) disebutnya mubalghabyah. Dalam kamus bahasa indonesia kata mubalighah adalah pendakwah. Dapat diartikan bahwa pendakawah atau orang yang berdakwah adalah orang yang mengajak kepada orang lain baik melalui lisan maupun tulisan ataupun perbuatan. 
Maudu atau pesan tabligh adalah pesan-pesan materi segala sesuatu yang harus disampaikan oleh muabaligh (subjek dakwah) kepada mubalaghah (objek dakwah). Yaitu keseluruhan ajaran Islam, yang ada di dalam kitabullah maupun sunah Rasul-Nya (Anahari, 1993:146).

Masalah pokok yang menjadi materi tabligh adalah akidah islamiah. Aspek akidah ini yang akan membentuk moral (aqidah) manusia. Oleh karena itu, yang pertama kali dijadikan materi dakwah tabligh Islam masalah akidah atau keimanan. Akidah yang menjadi materi utama ini mempunyai ciri-ciri yang membedakannya dengan kepercayaan agama lain.

Masalah Hukum atau syariah sering disebut sebagai cermin peradaban dalam pengertian bahwa ketika ia tumbuh matang dan sempurna, maka peradaban mencerminkan dirinya dalam hukum-hukumnya. Pelaksanaan syariah merupakan sumber yang melahirkan peradaban Islam, yang melestarikan dan melindunginya dalam sejarah. Syariah inilah yang akan selalu menjadi kekuatan peradaban di kalangan kaum muslim. Materi tabligh yang bersifat syariah ini sangat luas dan mengikat seluruh umat Islam. Ia merupakan jantung yang tidak terpisahkan dari kehidupan umat Islam di berbagai penjuru dunia, dan sekaligus merupakan hal yang patut dibanggakan. Kelebihan dari materi syariah Islam antara lain, adalah bahwa ia dimilik oleh umat-umat yang lain. Syariah ini bersifat universal, yang menjelaskan hak-hak umat muslim dan nonmuslim, bahkan hak seluruh uamat manusia. Dengan adanya materi syariah ini, maka tatana sistem dunia akan teratur dan sempurna.

Masalah Mu'amalah Islam merupakan agama yang menekankan urusan mu'amalah lebih besar porsinya dari pada urusan ibadah. Islam lebih banyak memerhatikan aspek kehidupan sosial dari pada aspek kehidupan ritual. Islam adalah agama yang menjadikan seluruh bumi ini masjid, tempat mengabdi kepada Allah. Ibadah dalam mu'amalah di sini, diartikan sebagai ibadah yang mencakup hubungan dengan Allah dalam rangka mengabdi kepada Allah SWT. Cakupan aspek mu'amalah jauh lebih luas dari pada ibadah.

Masalah Akhlak Secara etimologi, kata akhlak berasal dari bahasa Arab, jamak dari "khuluqun" yang berarti budi pekerti, perangai, dan tingkah laku atau tabiat. Kalimat-kalimat tersebut memiliki segi-segi persamaan dengan perkataan "khlqun" yag berarti kejadian, serta erat hubungannya dengan khlaiq yang bearti pencipta, dan "makhluk" yang bearti yang diciptakan. Sedangkan secara terminologi, pembahasan akhlak berkaitan dengan masalah tabiat atau kondisi temperatur batin yang memengaruhhi perilaku manusia. Ilmu akhlak bagi AlFarabi, tidak lain dari bahasan tentang keutaman-keutamaan yang dapat menyampaikan manusia kepada tujuan hidupnya yang tertinggi, yaitu kebahagaian, dan tentang berbagai kejahatan atau kekurangan yang dapat merintangi usaha pencapain tujuan tersebut.

Mubalagh adalah manusia yang menjadi sasaran tabligh baik sebagai individu maupun sebagai kelompok, baik manusia yang beragama Islam maupun 
tidak; atau dengan kata lain manusia secara keseluruhan. Mubalagh adalah seluruh manusia sebagai makhluk Allah yang dibebani menjalani agama Islam dan diberi kebebasan untuk berikhtiar, kehendak dan bertanggung jawab atas perbuatan sesuai dengan pilihannya, mulai dari individu, keluarga, kelompok, golongan, kaum, massa, dan umat manusia seluruhnya. Sebagai makhluk Allah yang diberi akal dan potensi kemampuan berbuat baik dan berbuat buruk, sebagai makhluk yang terkena sifat lupa akan janji dan pengakuannya bahwa Allah adalah Tuhannya ketika di alam ruh sebelum ruh tersebut bersatu dengan jasad. Manusia sebagai makhluk yang tidak hidup menyediri tetapi membutuhkan orang lain dalam memenuhi kebutuhannya. Kemudian, manusia dengan potensi ruhani yang dimilikinya dapat menerima dan menolak syari'at Islam yang diperuntuhkan dan berfungsi sebagai aturan dan pedoman kehidupan baik sebagai hamba maupun sebagai khalifah Tuhan di bawah bumi (Aliyudin, 2009:37).

Penelitian ini termasuk pada penelitian kualitatif deskriptif, metode penelitian ini akan menggambarkan dan menjelaskan data-data dari mengamatan lansung, lalu data yang di peroleh dan terkumpul dianalisis. Sehingga dapat menghantarkan penelitian dalam memperoleh data secara akurat berdasrkan pengumpulan dan pengolah data secara sestematis.

Peneliti menetapkan lokasi penelitian di dala al-fathoni thailand selatan. Hal ini dikarenakan lokasi yang mudah di jangkau oleh peneliti, karena lokasi berdekatan dengan tempat tinggal peneliti. Pendekatan kualitatif memusatkan perhatian pada prinsip-prinsip umum yang mendasari perwujudan sebuah makna dari gejala-gejala social di dalam masyarakat. Objek analisia dalam pendekatan kualitatif adalah makna dari gejala-gejala social dan budaya dengan menggunakan kebudayaan dari masyarakat bersangkutan untuk memperoleh gambaran mengenai ketegorisasi tertentu. Observasi yang dilakukan pada penelitian ini adalah observasi langsung dan terlibat pada materi tabligh Tuan Guru Haji Abdul Karim bin Hasbullah dengan mengadakan pengamatan secara langsung terhadap objek penelitian. Penggunaan teknik ini karena dalam penelitian ini terhadap beberapa fonomena yang harus diteliti secara langsung sehingga dapat diketahui kondisi objektif secara rinci dan jelas. Wawancara ini dilakukan dengan keluarga Tuan Guru Haji Abdul Karim bin Hasbullah, dilakukan untuk mendapat data-data yang tidak dijangkau melalui observasi.

\section{HASIL DAN PEMBAHASAN}

Penulis mengambil tempat penelitian di Pondok Pesantren Dala Pattani, dan disanalah Tuan Guru Baba tinggal dan menyebarkan ilmu agamanya. Dengan objek adalah orang - orang yang sering mengikuti pengajian Tuan Guru Baba. Pondok Dala memiliki tingkat integritas yang tinggi dengan masyarakat sekitarnya di Desa Dala dan menjadi rujukan moral bagi kehidupan masyarakat umum. Masyarakat sekitarnya Pondok memandang bahwa Pondok sebagai komunitas khusus yang ideal terutama dalam bidang kehidupan moral keagaman. Apalagi pimpinan Pondok Dala dikenal sebagai ulama, sehingga fungsi sebagai lembaga 
penyiran agama sangat berjalan elektif, tidak hanya dakwah di lingkungan masyarakat sekitar Pondok, akan tetapi juga di luar Kabupaten dan luar Provinsi.

\section{Karakteristik Tabligh Tuan Guru Baba Abdul Karim Hasbullah Naknawa}

Sebagaimana pendakwah yang lainnya, berbicara tentang metode berarti berbicara tentang cara atau jalan yang harus dilalui untuk menggapai suatu tujuan tertentu, bagi seorang mubalighah metode dakwah amatlah penting, sebabdengan itu akan menentukan keberhasilah suatu tabligh. Keberhasilan ini selanjutnya akan berpengaruh kepada jumlah jamaah dan juga bagaimana perubahan sikap yang terjadi kepadapara Jemaah. Dengan metode yang digunakan oleh Tuan Guru sejauh ini berhasil, karena dilihat dari jumlah jamaah yang sudah sangat banyak dan terdapat dimana - mana.

Dari penelitian yang saya lakukan yaitu dengan mengamati langsung bagaimana tuan guru memberi ceramah terhadap jamaahnya metode yang digunakan seperti metode ceramah adalah suatu teknik atau metode dakwah yang banyak diwarnai oleh ciri karakteristik bicara seorang Da'i dalam suatu aktivitas dakwah. Begitupun dengan Tuan Guru, beliau ketika menyampaikan dakwah Islam dengan menggunakan metode ceramah karena dirasa efektif dalam menyampaikan dakwah kepada banyak orang. Metode ceramaha Tuan Guru dengan maksud bertujuan untuk menyampaikan tentang kebenaran, petunjuk, peraturan yang merujuk kepada Al-Qur'an dan hadits. Metode ceramah juga dapat berkembang menjadi metode - metode yang lainnya, seperti metode diskusi dan tanya jawab.

Selain dengan menggunakan metode ceramah, Tuan Guru juga menggunakan metode tanya jawab, metode ini sangat efektif untuk pengajian pengajian, karena ada interaksi langsung antara mubaligh dan mubalighah sehingga ketika ada materi - materi yang tidak di mengerti akan ditanyakan langsung kepada sang mubaligh. Metode Tanya jawab sangat mempengaruhi bagaimana berjalannya suatu pengajian karena dengan adanya metode ini, para jamaah tidak akan merasa bosan hanya dengan mendengarkan ceramah dari sepihak saja. Tuan Guru juga menggunakan metode Tanya jawab agar para jamaah tidak merasa kebingungan apabila ada sesuatu yang masih kurang di fahami, tanya jawab ini bisa berlangsung ketika masih ada ceramah atau seusai ceramah tergantung daripada Tuan Guru dalam memberikan kesempatan untuk bertanya, atau bisa saja seorang jamaah dengan meminta maaf terlebih dahulu memotong proses ceramah dengan mengajukan beberapa pertanyaan sebelum sang jamaah lupa untuk menanyakan hal tersebut. Selain dengan metode tanya jawab dan ceramah, Tuan Guru juga menggunakan metode percakapan antar pribadi, atau bentuk pertanyaan yang ditanyakan langsung kepada Tuan Guru secara pribadi dan bukan di tempat pengajian, akan tetapi diluar pengajian seperti di pondok pesantren, di dalam rumah, atau ketika sedang ada kumpulan dengan Tuan Guru. Percakapan ini dilakukan tidak di sengaja ataupun di sengaja oleh beberapa jamaah atau santri di Pondok Pesantren Dala. Beberapa orang yang membutuhkan 
pencerahan akan dating langsung menemui Tuan Guru, apabila Tuan Guru tidak sedang dalam kesibukan maka beliau akan menjawab pertanyaan dengan menemui orang tersebut, apabila sedang dalam kesibukan maka orang tersebut akan diarahkan untuk bertanya kepada beberapa murid yang sudah dipercaya oleh Tuan Guru, atau yang di rasa sudah mampu untuk menjawab pertanyaan itu.Metode silaturahim juga kadang - kadang dilakukan oleh Tuan Guru, seperti mendatangi beberapa rumah Jemaah nya yang sedang sakit, atau berziarah, menurutnya dengan metode ini beliau akan memahami lebih dalam kondisi jemaahnya, sehingga beliau dapat memahami dan membantu beban moral para jemaahnya. Selain itu, metode ini sangat efektif dalam pengembangan dakwah Islamnya sebab dengan metode ini Tuan Guru akan mengetahui kondisi secara dekat para jemaahnya.

Selain beberapa metode yang telah dipaparkan diatas, metode halaqoh adalah metode yang Tuan Guru gunakan juga dalam dakwahnya, beliau akan membacakan beberapa ayat Al-Qur'an dan Hadits lalu para jemaahnya akan mendengarkannya, metode ini ia gunakan sebelum memulai pengajiannya. Dalam berbagai macam metode yang digunakan oleh Tuan Guru, semuanya adalah metode yang sangat umum dan juga sangat efektif bagi terselenggaranya dakwah Islam. Tentu, dari semua metode yang digunakan memiliki beberapa kekurangan dan juga kelebihannya masing - masing dalam pembawaannya. Kesemua metode harus digunakan sesuai dengan keadaan objek yang di dakwahi, dengan memperhatikan beberapa faktor seperti, usia, pengetahuan, social dan budaya serta yang lainnya. Dan itulah yang bisa dipaparkan atau hasil penelitian dari beberapa metode yang digunakan oleh Tuan Guru Baba dalam melakukan dakwahnya sehingga dakwahnya menjadi sangat mudah diterima dan difahami oleh mubalagh.

Muzakarah adalah diskusi, materi terserah kesepakatan yang telah di tentukan, muzakarah ini untuk meningkatkan keimanan pada diri sendiri dan islah diri sendiri agar tumbuh dalam diri manusia suatu gairah terhadapa amalan. Metode ini membantu meningkatkan keimanan seseorang apabila ia sungguh sungguh dalam pengamalannya. Metode ini dilakukan agar saling terbuka satu sama lain tentang permasalahan yang ingin dibahas dan dikaji. Metode ini sangat sering dilakukan oleh para santri guna mendapatkan pengetahuan yang lain, karena dalam metode ini semua orang bebas berpartisipasi di dalamnya.

Dari semua metode yang telah disebutkan dan dijelaskan diatas, tentu semua metode itu adalah metode yang sering dipakai dalam menyampaikan dakwahnya. Tuan Guru dengan berbagai metode yang ada memang paling sering menggunakan metode ceramah, jadi dengan menggunakan metode ceramah para mubalagh hanya mendengarkan dan berusaha memahami apa yang disampaikan oleh Tuan Guru, karena yang sering dilakukan oleh Tuan Guru adalah mengisi pengajian - pengajian dan sangat jarang sekali melakukan Tanya jawab. Proses Tanya jawab hanya dilakukan apabila ada luang waktu da nada kesempatan yang diberikan kepada mubalagh untuk bertanya.

Metode ceramah memang adalah hal yang lazim dilakukan oleh seorang 
pendakwah karena kebanyakan para pendakwah menggunakan metode ini sebagai media komunikasi yang ada. Metode ceramah yang dilakukan oleh Tuan Guru tentu sangat berpegaruh dalam menyampaikan pesa dakwahnya. Meski kebanyakan para pendakwah menggunakan metode ceraah akan tetapi selalu dibarengi juga dengan metode yang lain sehingga metode - metode yang digunakan semakin bervariasi dan tetap memberikan daya Tarik. Selain itu metode ceramah adalah hal yang lumrah dilakukan oleh para mubaligh. Metode ceramah sangat berguna dalam perkembangan keilmuan seputar agama Islam. Tuan Guru sangat sering menggunakan metode ceramah sebagai bentuk terbaik dan metode terbaik yang ia kuasai.(Tuan Guru, wawancara, 20 January 2018).

\section{Materi Tabligh Tuan Guru Baba Abdulkarim Hasbullah Naknawa}

Tuan Guru memberikan berbagai macam materi didalam pondok pesantren, sesuai dengan peraturan yangada di dalam pondok pesantren dala, diantaranya tentang materi tentang ilmu tauhid, ilmu fiqih, ilmu tasawuf, ilmu tafsir, dan masih banyak lainnya. Secara lengkap kita-kitab yang di pelajari di Pondok Dala adala sebagai berikut :

Tauhid: Tijn Ad-Darari, Matan As-Sanusiyyah, Ahl As Sunnahwaljama'ah, Al-Adwam. Kitab-kitab ini membahas tentang sifat wajib, Jaiz dan Mustahil bagi Allah dan para utusnya. Kitab ini juga menegaskan kepada seluruh umat islam yang sudah baligh dan berakal untuk mengetahui: Fiqih :Fath Al-Qurib, Fath AlMuin, Al-Bajuri, Fath Al-Wahhab Dan Al-Iqna. Kitab ini yang membahaskan tentang pendapat para ulama-ulama yang dulu tentang shalat, zakat, puasa, haji dan lain-lain. kitab ini harus di pahami oleh santri-santri dan bisa diamalkan dalam bentuk sehari-hari.

Hadits :Shahih Bukhari, Shahih Muslim, Riyad Ash-Shalihin, Bulugh AlMaram, Sunan Abu Dawud, Jwahir, Al-Bukhari, Tajrid As-Sariyyah, Ilmu Musthalah Al-Hadits. kitab ini adalah yang mengungkap tentang hukum-hukum Allah melalui Rasulullah yang kemudian di pelajari oleh santri Pondok Dala sesuai dengan jenjangnya. Adapun nama kita-kitab adalah

Tafsir : Tafsi Ibnu Katsir, Tafsir Jalalain, Tafsir Al-Munir, Tafsir Juz Amma, Tafsir Ali Ash-Shabuni, Darus At- Tafsir. Kitab-kitab ini menjelaskan beberapa hal yang menyangkut hal hokum-hukum Islam, sejara, cerita-cerita melalui interpretasi yang dimksud oleh ayat-ayat di dalamnya.

Usul Fiqih : Al-Waraqat, Lata'if Al-Isyarah, Ghayat Al=Ghayat Al-Ushul, Jam'al-Jawami, Al-Bayam, Al-Mabadi' Ash-Shahiyyah. Kitab ini membahas tentang faidah-faidah, aturan-aturan, pokok permasalah. Dengan kitab-kitab ini diharapkan santri-santri mampu mengali hukum-hukum islam dan mampu untuk memecahkan dari pokok masalah.

Tasawuf : Minhaj Al-Abidin Dan Hikam Ibnu Ata' kitab ini membahas tentang hakikat hidup manusia diantaranya menjelaskan tentang status dunia dan akhirat agar supaya santri mampu berbahagia di dunia dan akhirat.

Mantik : Munawwarah. Kitab ini menjekaskan cara berkomunikasi adat 
bercakapan dengan baik dan benar dirapkan dengan mempelajari kitab ini santri berkomunikasi dengan baik dan benar ketika di tengah-tengah masyarakat.

Akhlak : Ta'lim Al- Muta'alim, Uqud Al-Lujain. Kitab ini merupakan kitab penting oleh karena kitab ini dapat memberi bagi santri mengetahui akhlak-akhlak yang mulia dan akhlak yang bercela.bagi santri untuk dapat melakukan perubahan yang baik dan menjauhi hal yang tidak baik.

Bahasa Arab : Nahwu : Mutamminah, Ibnaqil, Ajurumiyyah, Imriti, Khawatib, Nazm Al-Fiyah, Syuzeaz-Zahab, Qawa'id Al-Lughah, Al-Fiyahibn Malik, Ami=Silat Al-I'rab. Sharaf : Kailani Izzi, Nazam Al-Maqasud, Al-Amsilat At-Tasrifiyyah, Mughni Al-Labib, Kafrawi. Balaghah : Jawahir Al-Maknun, AlLubb Al-Masahun. Tajwid : Tuhfat Al-Atfal.

Sedangkan ketika berada diluar pesantren, materi yang disampaikan akan tergantung kepada permintaan dari yang mengundang beliau untuk berdakwah, dan materi yang disampaikan akan sesuai dengan keadaan yang ada, misalnya ketika di undang untuk mengisi pengajian kepada anggota Haji maka materi yang disampaikan adalah seputar haji, pun ketika beliau di undang untuk mengisi di acara pernikahan maka yang beliau sampaikan juga adalah tentang pernikahan. Selain itu, beliau juga sering mengisi tabligh di hari-hari besar, seperti hari Isra' Mi'raj atau hari raya tahun baru Hijriah.(Tuan Guru, wawancara, 20 January 2018).

\section{Media TablighTuan Guru Baba Abdulkarim Hasbullah Naknawa}

Media tabligh berfungsi agar tabligh di permudah dan dimengerti, sehingga para mubalagh akan mudah memahami ketika seorang mubaligh menyampaikan pesan dakwahnya. Media tabligh bertujuan agar mubalagh bisa membedakan ciri - ciri khas yang di miliki oleh seorang mubaligh. Berikut adalah penuturan dari media tabligh yang digunakan oleh Tuan Guru Baba.

Lebih banyak komunikasi. adalah dengan komunikasi langsung beliau tidak banyak menggunakan media elektronik, media massa itu hanya sekedar saja, karena setiap beliau mengadakan pertemuan-pertemuan tidak pernah menggunakan semacam radio, televisi karena yang di harapkan adalah pengorbanan diri, yang menyampaikan dan mendengarnya, intinya lebih banyak dengan berkomunikasi langsung dan silaturrahmi. (Tuan Guru, wawancara, 20 January 2018).

Berbeda dengan para mubaligh yang lainnya, Tuan Guru Baba hanya menggunakan kata - kata dan retorika tubuhnya, tidak menggunakan media lainnya. Tuan guru Baba juga sering menggunakan media yang ada, seperti hal hal yang ada pada saat itu. Tuan guru Baba hanya lebih sering berceramah tanpa perantara apa - apa, tidak menggunakan media massa, media cetak ataupun media social, ia hanya sering melakukan dengan bertemu dan berkumpul bersama di sebuah majelis talim. Karena baginya, dakwah dengan semacam itu saja sudah cukup, apabila ada pihak lain yang berinisiatif merekam dirinya saat sedang berceramah atau mendokumentasikan dirinya, maka itu adalah bentuk lain dari suatu pengorbanan sebuah pihak yang ingin menyebarkan agama Allah dengan benar dan baik. Itulah beberapa hal yang menyangkut dengan media tabligh Tuan 
Guru.

Selain itu, beberapa informan memberikan tanggapan seputar media yang sering digunakan oleh Tuan Guru, menurut informan yang pertama ia menuturkan bahwa ketika berceramah Tuan Guru sering menggunakan media yang ada sebagai alat dakwah atau contoh yang akan digunakan untuk mencontohkan sesuatu, misalnya ketika ia sedang berbicara tentang berbakti kepada orangtua maka yang ia gunakan adalah orang - orang yang hadir disana pula sebagai contoh atas materi yang ia sampaikan.

Ada beberapa jenis media dakwah, diantaranya adalah lisan, tulisan atau gambaran, audio visual, perbuatan dan organisasi. Yang paling sering digunakan oleh Tuan Guru adaah media yang dalam bentuk komunikasi langsung ataupun tidak langsung, Ia sering menggunakan media social seperti Youtube yang ia gunakan untuk berdakwah, sebenarnya masuknya ia ke Youtube adalah karena ada seseorang yang merekam dan memasukannya kedalam media social atau ada seseorang yang mendokumentasikan beliau ketika sedang berdakwah sehingga beliau menjadi terkenal dan menyebarkan agama Islam dengan cepat dan luas.

Menurut informan yang kedua, ia menuturkan bahwa dalam dakwahnya Tuan Guru menggunakan kitab kuning sebagai media, ketika beliau menggunakan kitab kuning sebagai media, maka yang ia bahas adalah hal - hal yang ada didalam kitab kuning. Sedangkan menurut informan yang ketiga, ia menuturkan bahwa media yang digunakan oleh Tuan Guru selain kitab kuning Tuan Guru juga menggunakan al-Qur'an sebagai media dakwahnya, karena Tuan Guru sering membawa al-Quran dan mengutip ayat - ayat di dalamnya serta menjelaskan pengertiannya.

Dari semua uraian diatas bahwa setiap ulama atau pendakwah bisa saja menggunakan banyak media untuk melakukan proses dakwahnya, akan tetapi beberapa pendakwah yang lain memilih beberapa media saja yang digunakan untuk berdakwah sebab minimnya media dan minimnya dukungan dari berbagai pihak. Begitupun Tuan Guru Baba yang hanya menggunakan media seadanya dan sesuai dengan kebutuhannya saja, tidak seperti para pendakwah zaman sekarang yang mendapatkan banyak dukungan media dakwah, seperti menyebarkannya lewat televise, media cetak juga media social. Berbeda dengan di Fattani menyebarkan agama Islam tidak semudah yang ada di Indonesia, akan tetapi sangat lah sulit, tetapi hal itu tak membuat Tuan Guru kehilangan keinginan untuk menyebarkan agama Islam sebab dengan keyakinan yang ia miliki ia melakukan itu sesuai kehendak hati dan mematuhi perintah Allah swt.

Selain itu, media juga sangat berpengaruh terhadap perjalanan dakwah seseorang, apabila seorang pendakwah tidak memiliki media untuk berdakwah maka yang ia miliki hanyalah ilmu pengetahuan tanpa perantara hingga akhirnya akan kesusahan juga dalam menyampaikan dakwahnya. Tentu saja, apapun media yang digunakan oleh Tuan Guru tidak menurunkan semangat Tuan Guru untuk selalu melakukan dakwahnya sehingga ia terus melakukan dakwah dengan media yang dimilikinya. 


\section{Gaya Bahasa Tabligh Tuan Guru Baba Abdulkarim Hasbullah Naknawa}

Sebagai seorang pendakwah atau yang seringkali disebut Mubaligh, Tuan Guru memiliki pendidikan yang lumayan tinggi dan juga didukung oleh pendidikan non formal yang beliau dapatkan dari pesantren saat beliau mondok, sehingga beliau memiliki gaya bahasa yang mudah dipahami dan dimengerti oleh masyarakat yang berbeda - beda.

Ada beberapa unsur gaya bahasa yang digunakan oleh Tuan Guru, diantaranya adalah kejujuran, sopan santun dan selain itu juga menarik. Yang pertama adalah kejujuran, ini berarti beliau menggunakan kata - kata yang baik yang sesuai dengan kaidah - kaidah dalam berbahasa, sehingga ketika menyampaikan dakwah akan langsung kepada tujuan serta tidak berbelit - belit yang malah akan membuat para jemaahnya kebingungan. Penggunaan gaya bahasa yang tidak terarah akan menyebabkan kekacauan dalam dakwah.

Yang kedua adalah sopan santun, yang dimaksud dengan sopan santun disini bukanlah bahasa yang basa - basi dan tidak jelas, akan tetapi merupakan bahasa yang jelas yang langsung kepada tujuan dalam berdakwah, artinya beliau menyampaikan pesan dakwahnya dengan sangat jelas dan tidak membuat mubalagh nya kesulitan dalam memahami dakwah beliau. Dengan menggunakan gaya bahasa yang jelas, maka tabligh tidak akan keluar dari alur yang ada sehingga tidak membat mubalagh bingung. Selain kejujuran dan sopan santun, gaya bahasa juga dibuat semenarik mungkin agar mubalagh tidak merasa jenuh dan bosan ketika mendengarkan tabligh.

Sedangkan jenis bahasa yang digunakan oleh Tuan Guru tergantung daripada tempat dimana beliau berdakwah, dan kebanyak beliau menggunakan dakwah dengan bahasa Melayu dan Thailand, tergantung dimana beliau menyampaikan dakwahnya. Akan tetapi kebanyak beliau melakukan dakwahnya di Thailand sehingga bahasa yang digunakan adalah bahasa Thailand. Selain itu, bahasa Thailand juga adalah bahasa yang fasih bagi beliau karena beliau lahir dan besar disana.

Dengan memperhatikan keadaan mubalaghnya beliau menggunakan gaya bahasa yang mudah dicerna oleh kebanyakan orang, beliau tidak menggunakan bahasa yang tinggi atau yang sering disebut bahasa yang terlampau intelek, karena jika beliau menggunakan gaya bahasa yang demikian itu malah akan membuat mubalagh nya kebingungan sehingga tidak akan mudah dicerna dan dipahami oleh oranglain.

Dengan menggunakan gaya bahasa yang baik, itu membuat dakwah beliau semakin maju dan berkembang sebab sangat mudah diterima dan difahami oleh masyarakat yang ada. Beliau tidak pernah menyinggung siapapun dan selalu meluruskan kesalafahaman atau hal - hal yang membuat mubalaghnya bingung ketika mendengarkan dakwahnya. (Abdullah, wawancara, 27 January 2018).

Dari uraian diatas dapat diberi penjelasan bahwasannya setiap pendakwah memiliki gaya bahasaa yang bermacam - macam dalam menyampaikan dakwahnya, diantaranya adalah Tuan Guru memiliki gaya bahasa yang baik dan 
benar, beliau menyampaikan sesuai dengan keadaan para jemaahnya dan beliau sangat memahami mereka. Ini menunjukan bahwa apa yang Ia lakukan adalah dakwah terbaik dengan penyampaian yang baik pula. Baliau menggunakan kata kata yang tegas dan menyentuh meskipun jarang sekali memiliki selera humor akan tetapi masih bisa diterima oleh para Jemaah juga menjadi motivasi.

Dalam perembangan dakwahnya, Tuan Guru memiliki gaya bahasa yang beragam dalam menyampaikan dakwahnya. Tuan Guru memiliki banyak kelebihan sehingga apa yang ia lakukan sangatlah berpengaruh terhadap perkembangan dakwahnya. Sama halnya dengan para pendakwah yang lainnya, Tuan Guru memiliki gaya bahasa yang tegas namun lembut dalam menyampaikan dakwahnya.

\section{Pemirsa Tabligh Tuan Guru Baba Abdulkarim Hasbullah Naknawa}

Tuan Guru dalam menyampaikan dakwah Islamnya tidak hanya di Pondok Pesntren, akan tetapi sampai ke luar Negara, seperti Malaysia dan beberapa kota yang ada di Malasysia. Ini membuktikan bahwa Pondok Pesantren Dala yang telah berdiri sejak lama telah popular di kalangan para pencari ilmu pengetahuan seputar agama. Selain di pesantren, Tuan Guru juga mengisi ceramah di berbagai tempat di kota - kota yang ada di Thailand. Selain wilaayah yang sudah mencapai luar Negara, beberapa kota yang ada di Thailand pun sudah berhasil dirambah oleh pergerakan dakwah Tuan Guru, sehingga beliau menjadi tokoh yang terkenal sebagai pedakwah yang produktif di negaranya termasuk Patani.

Kepopuleran beliau didalam lingkup dakwah Islam tak lain hasil dari kerja kerasnya dalam berdakwah, sehingga beliau mencapai ekspansi yang luar biasa dalam dakwahnya. Selain dari beberapa pencapaian luar biasa yang beliau dapatkan, beliau juga menjadi mubaligh yang sering dipanggil untuk menyampaikan dakwah Islamnya. Dalam melakukan dakwah Islam, beliau sangat bersungguh - sungguh melakukannya sehingga sampai terkenal di beberapa kota dan wilayah dakwahnya menyebar sangat luas.

Selain diluar kota atau bahkan Negara, beliau juga paling sering melakukan dakwah didalam pondok pesantren, sebab menurut beliau bahwa ia harus sering memberikan semangat dan ilmu - ilmu agama kepada santri - santrinya untuk kemudian para santri yang telah dididik diharapkan mampu meneruskan perjuangan dakwah yang beliau lakukan. Meskipun beliau memiliki undangan yang sangat luar biasa padatnya, akan tetapi tetap beliau mengajar di Pondok nya sebagai bentuk pengabdiannya dan tidak melalaikan tanggung jawab di pondok

Dalam berdakwah, tentu para pendakwah akan menghadapi beberapa jenis masyarakat yang berbeda, semisal masyarakat yang berada di Kota dan masyarakat yang ada di desa, tergantung dimana mereka tinggal. Selain dari pembagian masyarakat desa dan kota, juga ada masyarakat dari kalangan menengah kebawah dan menengah keatas. Semuanya tergantung kepada tempat dimana mereka tinggal. Meskipun begitu, tak lantas membuat Tuan Guru menjadi sngat pilih pilih terhadap masyarakat yang mengundangnya,justru ia tetap memperlakukan 
mereka dengan sama, dengan rasa hormat yang sama dan dengan pengetahuan yang sama pula, Tuan Guru tidak membeda - bedakan mana yang harus dibentuk Islami dan mana yang tidak.

Tuan Guru Haji Baba dalam menyampaikan dakwahnya banyak melakukan di pondok pesantren Dala, karena pesantren tersebut berada dibawah pimpinannya sehingga membuatnya menjadi sangat bertanggung jawab terhadap Pondok Pesantren Dala. Di pondok pesantren Dala memiliki santri dengan usia 13-30 tahun, sehingga sangat beragam sekali. Selain itu, ada beberapa santri dari kelas menengan keatas juga menengah ke atas. Tentu saja Tuan Guru Baba memiliki mubalagh yang berbeda - beda, baik dari umur, social maupun budaya nya. Seperti orang Thailand asli dengan orang melayu, yang tentu dari segi budaya dan bahasa sudah berbeda. Kebanyak orang Malaysia adalah orang - orang dengan tingkat social dan kesejahteraan yang tinggi disbanding dengan orang Thailand (Patani) yang rata - rata penduduk desa yang biasa - biasa saja. Tentu, ketika mubalagh nya berbeda dari segi manapun, Tuan Guru juga akan menyesuaikan sesuai dengan mubalagh yang ada sehingga tidak terjadi kesalahfahaman atau kebingungan dalam menjalankan dakwahnya.

Selain Tuan Guru mengisi di beberapa wilayah yang telah disebutkan diatas, meskipun wilayahnya tidak tetap dan beliau selalu mengisi pengajian dengan berbagai tempat, akan tetapi beliau tetap memiliki tempat yang tetap untuk menyampaikan pesan dakwahnya, yaitu di pondok pesantren, karena menurutnya sebelum ia pergi ke tempat yang lain, ia akan berusaha memperbaiki dan meningkatkan kepribadian yang baiknya didalam pondok pesantren dulu.(Tuan Guru, wawancara, 20 January 2018).

\section{PENUTUP}

Karakteristik dari dakwah Tuan Guru adalah dengan menggunakan metode metode yang juga lumrah digunakan oleh para mubaligh lainnya, seperti metode ceramah, diskusi, Tanya jawab dan lainnya. Selain itu, materi - materi yang disampaikan juga kebanyakan tentang tauhid dan tasawuf. Dakwah yang dilakukan oleh Tuan Guru juga tidak hanya berada di wilayah pesantren saja, akan tetapi sampai keluar pesantren dan memiliki banyak. Sedangkan untuk jemaah tabligh Tuan Guru pun berbeda - beda, ada yang berasal dari kalangan menangah kebawah juga ada yang kalangan menengah keatas, dan semua usia juga termasuk daripada jemaahnya.

Dakwah Tuan Guru memiliki keberhasilan yang sangat tinggi karena mampu memotivasi seluruh santri dan orang - orang yang mengikuti pengajiannya, itu dibuktikan dengan tanggapan - tanggapan yang disampaikan oleh para informan mengenai Tuan Guru. Mengingat peranan mubaligh sangat penting dalam proses perubahan masyarakat maka dalam kerangka membangun eksistensi belajar, penulis menyarankan bahwa seorang mubaligh tidak hanya menjadi contoh yang baik untuk dirinya akan tetapi untuk orang lain pula. Agar masyarakat semakin tertarik untuk melakukan proses belajar maka di usahakan 
M. Y. Salaeh, \& A. Shodiqin

harus ada gerakan - gerakan yang sangat menarik pula ketika berdakwah, seperti menjalankan wisata belajar agama dan yang lainnya. Seorang mubaligh diharapkan memahami keadaan para Jamaah, sebab dengan memahaminya maka akan membangun sikap saling percaya dan transfer ilmu semakin mudah. Seorang mubaligh diharapkan mengerti perkembangan zaman akan tetapi dengan tidak menghilangkan dasar keIslaman didalamnya. Tidak hanya seorang mubaligh, akan tetapi para Jemaah juga diharapkan semakin termotivasi untuk melakukan kebaikan dan selalu bersemangat mengikuti pengajian - pengajian.

\section{DAFTAR PUSTAKA}

Aliyudin Enjang, 2009, Dasar-dasar Ilmu Dakwah, Bandung : Widya Padjadjaran. Al-Qahthani, Ali. 1994, Da'wah Islam Dakwah Bijak, Jakarta : Gema Insani Press. Amin, 2000, Islam Kebudayaan Jawa, Yokyakarta : Gama media. Anahari, 1993, Pengantar Pengalaman Dakwah, Surabaya : al-Iklas.

Depag (2009) Qur'an an-Nahl 125, Bandung : Jabal Raudhatul Jannah.

Kusnawan Aep, 2004, Komunikasi dan Penyiaran Islam, (Mengembangkan

Tabligh Melalui Mimbar, Media Cetak, Radio, Televise, Film, Dan Media Digital), Bandung: Benang Merah Press.

Kusnawan Aep, 2016, Teknik Menulis Dakwah, Bandung : Simbiosa Rekatama Media.

Ma'arif Bambang, 2010, Komunkasi Dakwah Paradikma Untuk Aksi, Bandung : Simbiosa Rekatama Media.

Muhyidin Asep , 2002, Metode Pengembang Dakwah, CT Pustaka Setia : Rosdakarya Bandung.

Subandi, 1994, Ilmu Tabligh Pengantar Metodelogi, Bandung : Yayasan Syahida. Syihata Abdullah, 1978, Da'wah Islamiyah, Ditjen Binbaga Islam Depag Ri.

Syukri Asmuni, 1983, Dasar-dasar Strategi Dakwah, Surabaya : al-Ikhlas. 